\title{
Development of porcine rotavirus vp6 protein based ELISA for differentiation of this virus and other viruses
}

Jiayi Zhu ${ }^{1,2 \dagger}$, Qing Yang ${ }^{3 \dagger}$, Liyan Cao ${ }^{1}$, Xiujing Dou' ${ }^{1}$, Jianguo Zhao ${ }^{4}$, Weijuan Zhu' ${ }^{1}$, Fan Ding ${ }^{1,5}$, Ri-e Bu ${ }^{2}$, Siqingaowa Suo ${ }^{1}$, Yudong Ren ${ }^{1}$, Guangxing $\mathrm{Li}^{1}$ and Xiaofeng Ren ${ }^{1,2^{*}}$

\begin{abstract}
Background: The context and purpose of the study included 1) bacterial expression of viral protein 6 (VP6) of porcine rotavirus (PRV) and generation of rabbit polyclonal antiserum to the VP6 protein; 3) establishment of a discrimination ELISA to distinguish PRV from a panel of other porcine viruses.

Results: The VP6 gene of PRV isolate DN30209 amplified by reverse transcription-PCR was 1356 bp containing a complete open reading frame (ORF) encoding 397 amino acids. Sequence comparison and phylogenetic analysis indicated that PRV DN30209 may belong to group A of rotavirus. Bacterially expressed VP6 was expressed in E.coli and anti-VP6 antibody was capable of distinguishing PRV from Porcine transmissible gastroenteritis virus, Porcine epidemic diarrhea virus, Porcine circovirus type II, Porcine reproductive and respiratory syndrome virus, Porcine pseudorabies virus and Porcine parvovirus.
\end{abstract}

Conclusions: PRV VP6 expressed in E. coli can be used to generate antibodies in rabbit; anti-VP6 serum antibody can be used as good diagnostic reagents for detection of PRV.

Keywords: PRV, VP6 gene, Cloning, Expression

\section{Background}

Rotavirus, a member of family Reoviridae, is one of the causative agents of viral diarrhea in young children and animals worldwide [1-3]. Rotavirus is approximately 75 $\mathrm{nm}$ in diameter and has multilayered icosahedral protein capsid composed of an outer layer, an inner layer, and a core [4]. The virus genome is comprised of 11 segments of double-stranded RNA, encoding six structural proteins (VP1-VP4, VP6, VP7) and six nonstructural proteins (NSP) [5,6]. The outer capsid layer proteins of rotavirus, VP4 and VP7, may elicit neutralizing antibodies independently; in addition, the two proteins can be used to classify rotaviruses into P and G genotypes, respectively [7-9].

\footnotetext{
* Correspondence: rxfemail@yahoo.com.cn

${ }^{\dagger}$ Equal contributors

${ }^{1}$ College of Veterinary Medicine, Northeast Agricultural University, 59 Mucai

Street, Xiangfang District, Harbin 150030, China

${ }^{2}$ School of Life Science, Inner Mongolia University for the Nationalities,

Tongliao, Inner Mongolia, China

Full list of author information is available at the end of the article
}

VP1, VP2 and VP3 proteins consist of the rotavirus core particles. VP1 was partially accessible to iodination in single-shelled particles [10]. The accession degree of VP1 to the immune system may affect the reaction of anti-PRV to VP1 protein [4]. VP2 is the most abundant structural protein in core particles [11]. Anti-VP2 serum is a good indicator of prior infection due to its high immunogenicity [12]. VP3 is a minor structural protein that may comigrate with the outer capsid protein VP4 in many gel systems and it may be involved in RNA replication; VP4 is cleaved to form VP5 and VP8 $[4,11]$.

VP6 is the major structural protein in virus particles located on the outer surface of single-shelled particles, in addition, VP6 is known as a subgroup antigen [4]. VP6 is required not only for polymerase activity and but also for maintaining the proper structure of the viral core or the core protein-based transcriptional complex. Myristylation of VP6 is required for virus particle formation as well as targeting single-shelled particles to the ER membrane for budding [13]. As VP6 is both highly 
immunogenic and antigenic, it is the most frequently used in diagnostic assays to detect PRV [14]. Herein, we expressed the VP6 gene from a PRV Chinese isolate DN30209 by cloning this gene into a bacterial expression system. We then generated rabbit polyclonal anti-serum and ascertained its immunoreactivity to VP6 protein. Using the anti-VP6 antibody, we established a differentiating ELISA for PRV. These experiments provided basis for determination of PRV.

\section{Results and discussion}

\section{Cloning and phylogeny of VP6 gene of PRV}

PRV may cause piglet diarrhea andV P6 is an important structural component of viral particles. In this study, we cloned the VP6 gene from a Chinese PRV isolate DN30209. The sequencing results showed that the cloned VP6 gene was 1356 bp containing a complete open reading frame (ORF) encoding 397 amino acids. The sequence has been submitted to GenBank and was allocated a GenBank accession number (JN977137). Compared with PRV JL94, there were three mutations at $\mathrm{N}_{94} \mathrm{H}, \mathrm{G}_{126} \mathrm{R}$ and $\mathrm{I}_{182} \mathrm{~V}$; compared with PRV GD, three mutations $\mathrm{N}_{94} \mathrm{H}, \mathrm{I}_{182} \mathrm{~V}$ and $\mathrm{T}_{244} \mathrm{~A}$ were identified. As DN30209, JL94 and GD all were isolated from northern China, these viruses may be geographical prevalent in northern areas in China. Based on the randomly selected PRV reference strains, the VP6 amino acid sequences were compared. As shown in Figure 1, PRVs DN30209 and several PRV group A strains OSU, JL94 GD, CRW-8, 4F and 4S etc. had more than 90\% homologous identity at amino acid level. RNA-PAGE analysis showed that the rotavirus represented long electropherotype migration pattern of porcine group A rotaviruses (Figure 2). Further phylogenetic tree analysis also indicated that PRV DN30203 located in the same clade with above-mentioned PRV group A strains (Figure 3). Therefore, we speculate that PRV DN30209 also belongs to group A of rotavirus. Nevertheless, it is necessary to do more serological and epidemiological investigations to get full understanding on the evolution of PRV in the future.

\section{Analysis of VP6 expression and immunoreactivities of its antibody}

It is clear that E. coli system has advantages such as low costs, high production, and manipulation convenience, etc. [15]. In our laboratory, we have expressed several heterologous proteins in this system [16-19]. In this study, we analyzed the bacterial expression of VP6 protein in E.coli. SDS-PAGE showed that fused VP6 protein was approx. $48 \mathrm{kDa}$ as expected and accumulated in the bacteria as inclusion bodies (Figure 4). In this study, a rabbit anti-VP6 antibody was generated by conventional animal immunization. The optimization of the ELISA was determined. As shown in Figure 5, after the fixation of the concentration of PRV VP6 protein, the optimal antibody dilution was $1: 2^{9}$. In addition to reaction with VP6 protein, at such dilution, the anti-VP6 serum also had the best reactivity to PRV. The optimization of the ELISA may be useful reference to detect PRV from clinical samples in the future. The reactivity of the protein to anti-VP6 antibody was then analyzed by Western blot. Our result showed that the bacterially expressed VP6 can be recognized by the antiserum, confirming that the VP6 is both highly immunogenic and antigenic (Figure 6). The immunoreactivity of the anti-VP6 antibody to

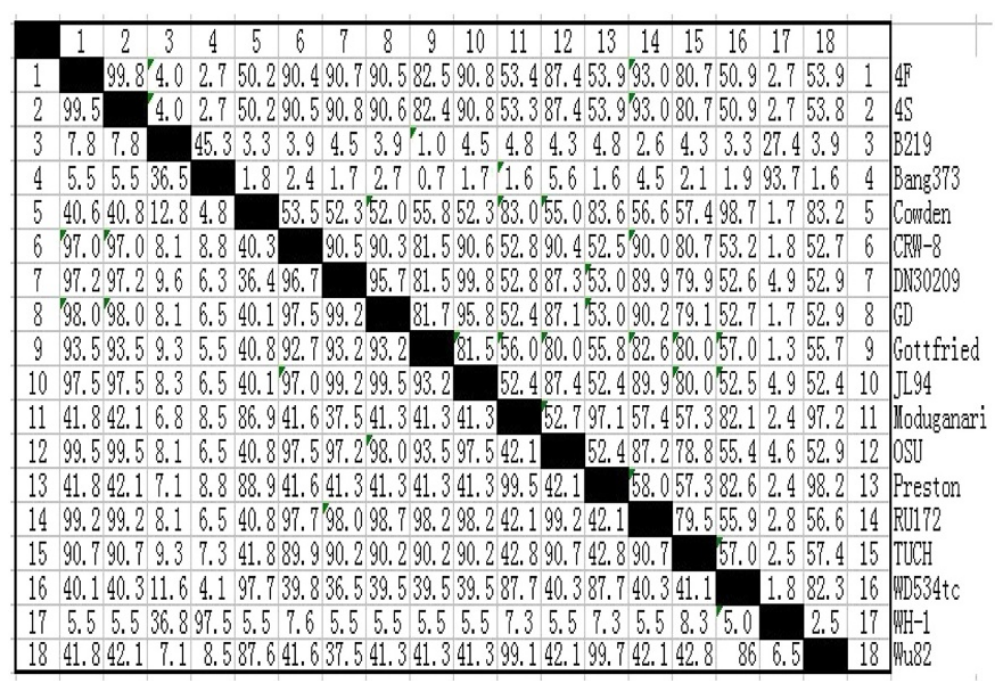

Figure 1 Homologous identity comparison of PRV VP6 gene. VP6 sequences of PRV isolates used in this study were subjected to multiple sequence alignments using the DNAStar software. Their grouping, name and origin are shown in Table 1. 


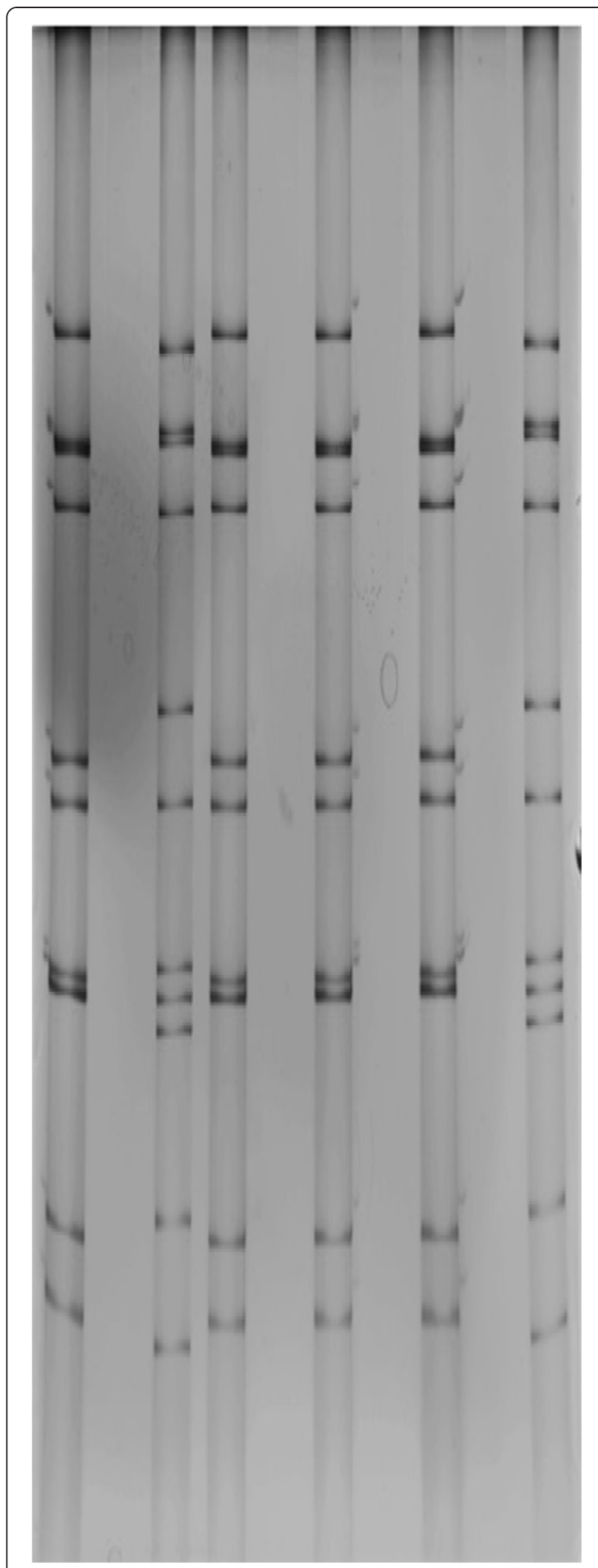

Figure 2 RNA-Polyacrylamide gel electrophoresis (PAGE) of PRV. RNA-PAGE profile shows long electropherotype migration pattern of PRV DN30209 (lane 1). Lane 2 is negative sample. eukaryotically expressed VP6 was further analyzed by IFA. As shown in Figure 7, the antibody reacted with VP6-expressing cells; in contrast, no green signal was detected in mock-transfected cells, confirming the specific recognition of the anti-VP6 antibody. In this study, the anti-VP6 antibody was generated by inoculating rabbit with VP6 expressed from E.coli, however, this antibody reacted with VP6 protein transiently expressed on cells. These data further confirm that bacterially expressed VP6 can be used as a good immunogen and the antibody can be used as good diagnostic reagent for detection of PRV VP6 protein.

\section{Discrimination ELISA for detection of PRV}

Like PRV, TGEV and PEDV are capable of causing diarrhea symptoms in pigs. Other porcine viruses may cause co-infection with PRV, thus, discrimination between PRV and other viruses is important for clinical diagnosis purpose. Recently, we have confirmed that the antiserum to VP7 protein of PRV may also serve as a diagnostic agent for detection of PRV (unpublished data). Nevertheless, it has been pointed out that PRV VP6 protein is the most frequently target protein in diagnostic assays to detect virus particles. As ELISA is simple, convenient and sensitive immunological assays suitable for detection of pathogens [19-22], a discrimination ELISA for detection of PRV was established using the anti-VP6 antibody. Several control viruses were included in the ELISA to determine the specificity of the ELISA. The result showed that the anti-VP6 antibody had significant reactivity with PRV; in contrast, there was no positive $\mathrm{P} / \mathrm{N}$ value among other controls $(p<0.01)$ (Figure 8$)$. Our results have demonstrated clearly that the VP6-antibody based ELISA works well in our laboratory, however, validation of the test using clinical samples are important so that the test can be applied in the field level for detection of PRVs. Thus, we will evaluate the utility of this VP6-antibody based ELISA in nature by including PRV clinical samples in the future.

\section{Methods}

\section{Amplification of VP6 gene of PRV by PCR}

PRV Chinese isolate named DN30209 was recently isolated in a pig farm in Heilongjiang Province, northeastern China. The virus was propagated in MA104 cells in presence of trypsin at a final concentration of $3 \mu \mathrm{g} / \mathrm{mL}(\mathrm{w} / \mathrm{v})$. The viral total RNA was extracted with a commercial kit according to the manufacturer's instructions (HaiGene, China). Sense primer (VP6-1): 5'- GGCTTTTAAACGAAGTCTTC and antisense primer (VP6-2): 5'- GGTCACATCCTCTCACTA were published primers [23] and used to amplify the VP6 gene for sequencing. The reverse transcription mixture included $5 \mu \mathrm{L}$ of RNA $(1 \mu \mathrm{g}), 1 \mu \mathrm{L}$ of primer VP6-2 (10 pmol), $4 \mu \mathrm{L}$ of $5 \times$ RT-PCR buffer (TaKaRa, China), 0.5 $\mu \mathrm{L}$ of RNase inhibitor, $1 \mu \mathrm{L}$ of dNTP $(10 \mathrm{mM} /$ each $), 1 \mu \mathrm{L}$ 


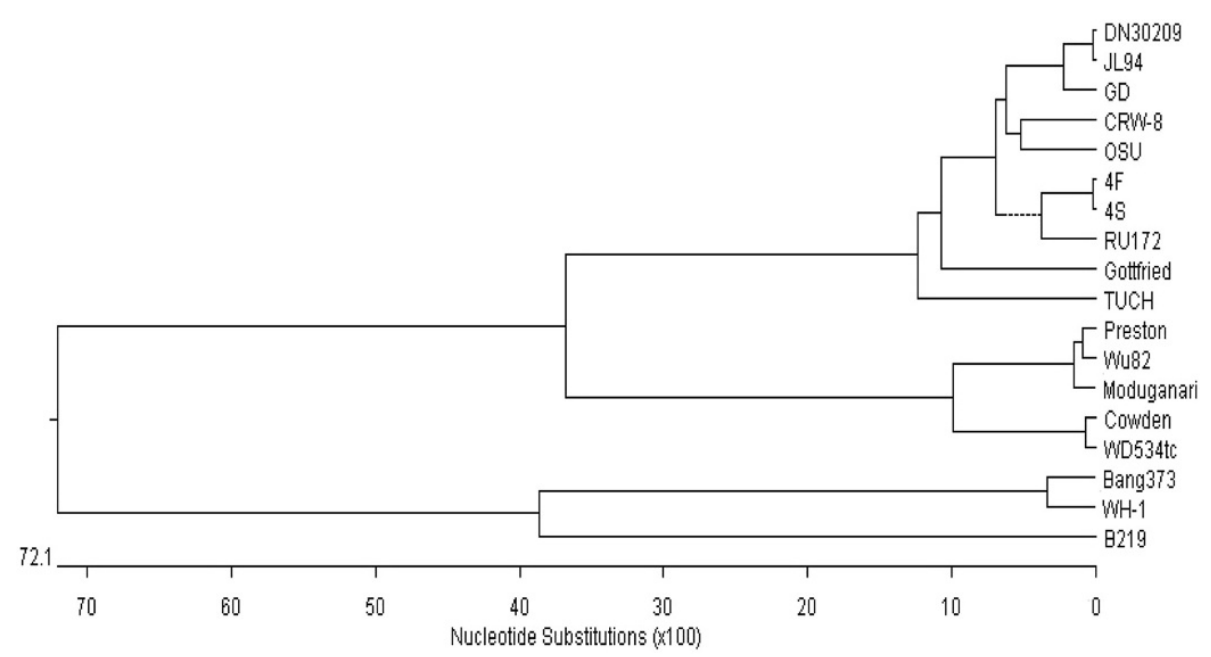

Figure 3 VP6 amino acide-based phylogenetic tree. A phylogenetic tree was constructed based on these PRV VP6 amino acid sequences using DNASTAR software.

of M-MLV reverse transcriptase (TaKaRa) and $7.5 \mu \mathrm{L}$ of sterile water. The reaction was performed at $30^{\circ} \mathrm{C}$ for $10 \mathrm{~min}, 42^{\circ} \mathrm{C}$ for $60 \mathrm{~min}$ and $95^{\circ} \mathrm{C}$ for $5 \mathrm{~min}$. Subsequent PCR mixture included the resulting $3 \mu \mathrm{L}$ of cDNA $(3 \mu \mathrm{g})$, $5 \mu \mathrm{L}$ of $10 \times$ ExTaq buffer, $1 \mu \mathrm{L}$ of each primer $(10 \mathrm{pmol})$, $4 \mu \mathrm{L}$ of dNTP $(2.5 \mathrm{mM} / \mathrm{each}), 0.25 \mu \mathrm{L}$ of ExTaqDNA (TaKaRa, China) and $35.75 \mu \mathrm{L}$ of sterile water. The PCR was performed at $94^{\circ} \mathrm{C}$ for $5 \mathrm{~min} ; 30$ cycles of $94^{\circ} \mathrm{C}$ for $40 \mathrm{~s}, 52.8^{\circ} \mathrm{C}$ for $40 \mathrm{~s}$, and $72^{\circ} \mathrm{C}$ for $1 \mathrm{~min}$; a final extension at $72^{\circ} \mathrm{C}$ for $10 \mathrm{~min}$. The PCR product was purified and subjected to DNA sequencing.

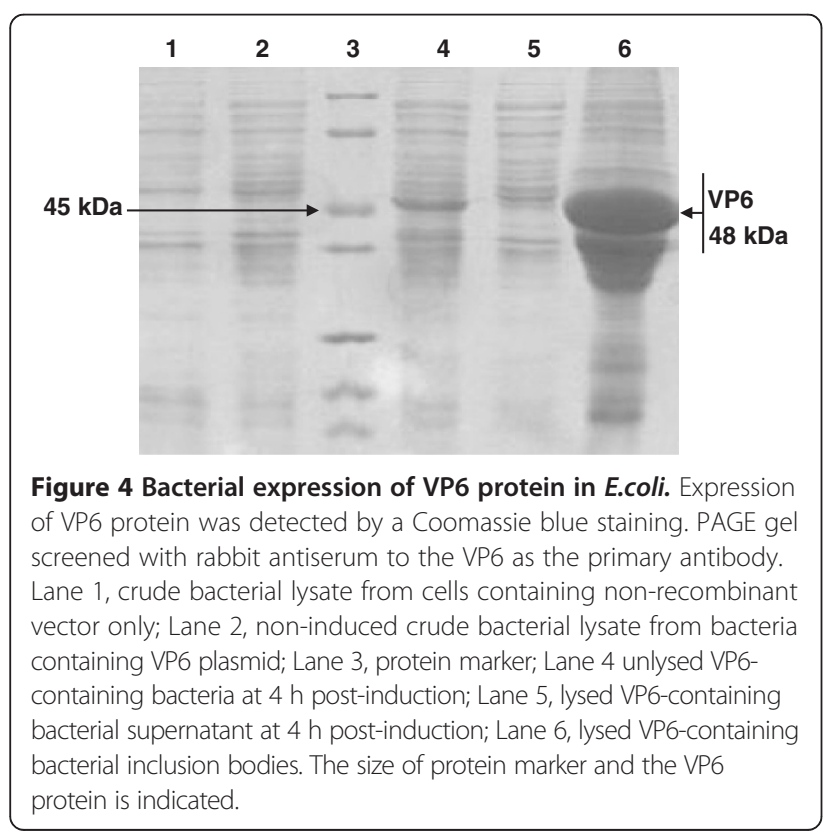

\section{RNA-polyacrylamide gel electrophoresis (PAGE)}

RNA of the PRV was extracted by mixing the virus suspension in PBS or PBS (negative control) with an equal volume of an extraction buffer $(0.02 \mathrm{M}$ Tris- $\mathrm{HCl} \mathrm{pH} 7.4$, $0.3 \mathrm{M} \mathrm{NaCl}, 0.01 \mathrm{M} \mathrm{MgCl}_{2}, 0.1 \%$ SDS, $5 \mu \mathrm{M}$ EDTA, $4 \%$ sucrose and $0.04 \%$ bromophenol blue) followed by phenol-chloroform extraction at $12,000 \mathrm{rpm}$ and $4^{\circ} \mathrm{C}$ for 10 min. The resulting supernatant was subjected to RNAPAGE to detect and analyze the genome of rotavirus. The RNA-PAGE was performed in $10 \%$ polyacrylamide slab gel using discontinuous buffer system without SDS as described by Laemmli [24] for $13 \mathrm{~h}$ at $10 \mathrm{~mA}$. Viral RNA segments were visualized in silver staining.

\section{Sequence comparison and phylogenetic analysis}

The obtained VP6 sequence was deposited in GenBank database and compared with reference PRV VP6 sequences

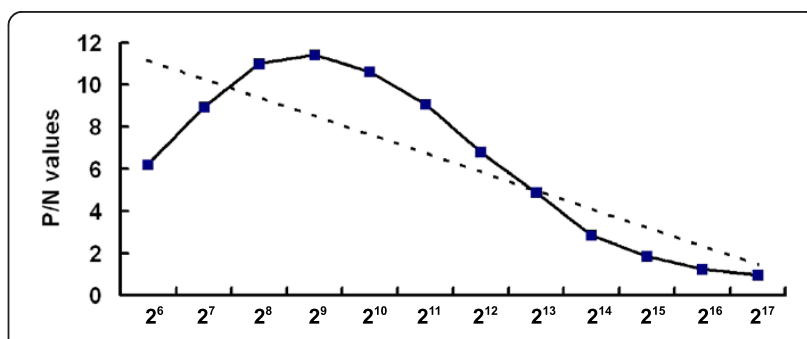

Figure 5 Optimization of dilution of anti-VP6 antibody in ELISA.

Purified VP6 protein ( $5 \mathrm{\mu g} /$ well) was diluted and coated in ELISA wells, and the serially diluted anti-VP6 antibody was used as primary antibody in subsequent ELISA. Dilutions of anti-VP6 antibody are indicated. The $\mathrm{OD}_{490}$ value of tested samples $(\mathrm{P}) /$ the $\mathrm{OD}_{490}$ value of negative control, coating buffer $(\mathrm{N})>2$ is judged as positive and shown as a curve; the broken-line is trend line. 


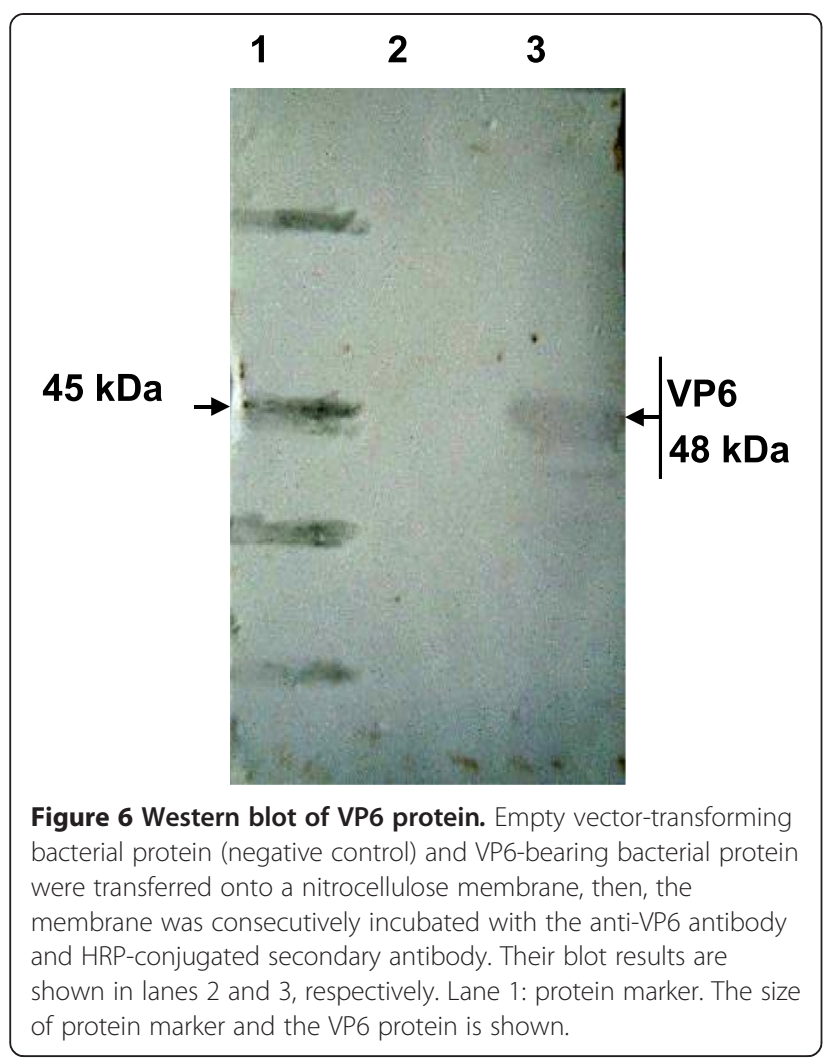

using DNASTAR software. The name, GenBank accession number and virus isolation location of these genes are shown in Table 1. At the same time, a phylogenetic tree was constructed by neighbor-joining method base on these VP6 amino acid sequences using the DNASTAR program [25-27]. The bootstrap probabilities of each node were calculated using 1,000 replicates.

\section{Construction of recombinant plasmids bearing VP6 gene and its bacterial expression}

To construct expression plasmids bearing the VP6 gene, forward primer: 5'- CCCCGGATCCATGCAAAATTACG GA(VP6F) and reverse primer (VP6R) 5'- GGGGAAGC TTGTTAGACTCGGTAATA were self designed and used to re-amplify the VP6 gene using the obtained PCR product above as template. Both primers contained BamH I and EcoR I sites, respectively. Subsequent PCR was performed as above using the full-length VP6 gene as template. The PCR profile included $95^{\circ} \mathrm{C}$ for $5 \mathrm{~min} ; 30$ cycles of $95^{\circ} \mathrm{C}$ for $30 \mathrm{~s}, 52.8^{\circ} \mathrm{C}$ for $30 \mathrm{~s}$, and $72^{\circ} \mathrm{C}$ for $2 \mathrm{~min}$ as well as a final extension at $72^{\circ} \mathrm{C}$ for $10 \mathrm{~min}$. The resulting PCR product was inserted into the prokaryotic expression vector pET30a and eukaryotic expression vector pVAX-1 to generate recombinant plasmids pET30a-VP6 and pVAX-VP6, respectively.

The pET30a-VP6 was transformed into Escherichia coli (E. coli) Rosetta. The transformed E.coli was
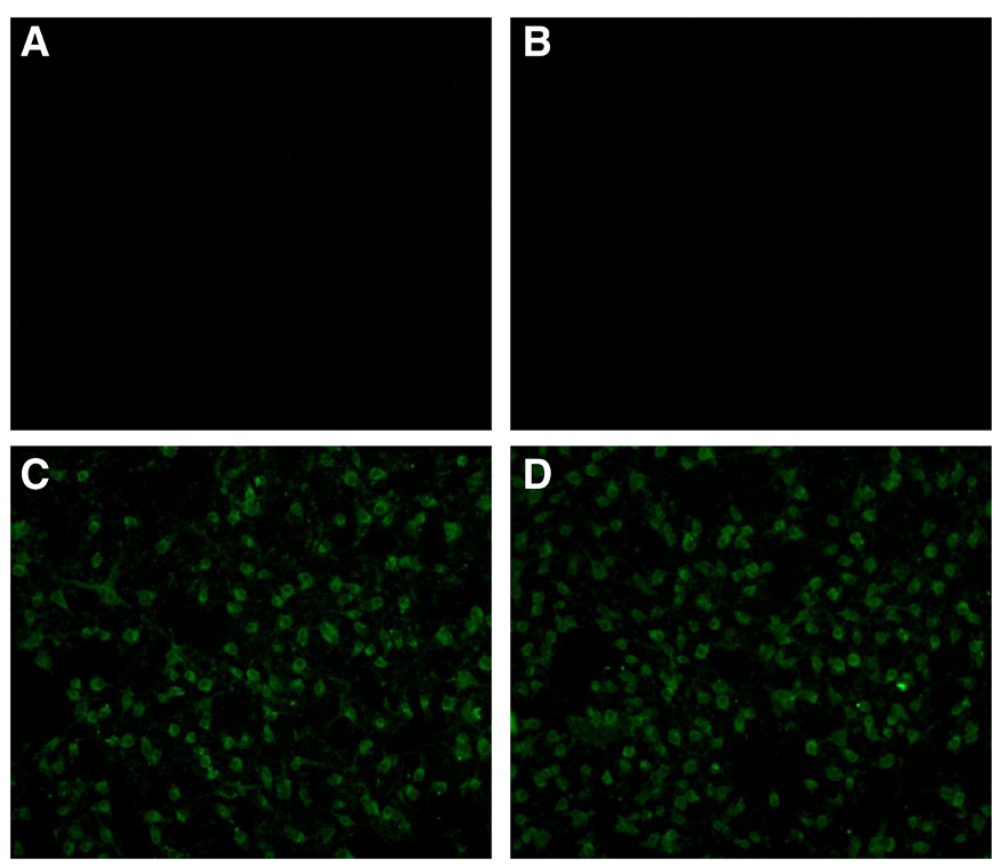

Figure 7 Immunofluorescence assay of cell surface expression of VP6. BHK cells were transfected with pVAX-VP6, then the cells were subjected to indirect immunofluorescence using anti-VP6 antiserum as primary antibody followed by incubation of FITC-conjugated secondary antibody (see M\&M). A representative comparison is provided. A: vector-transfected cells with treatment of Triton X-100; $\mathbf{B}$ : vector-transfected cells without treatment of TritonX-100; C: VP6-transfected cells with treatment of Triton X-100; D: VP6-transfected cells without treatment of Triton X-100. 


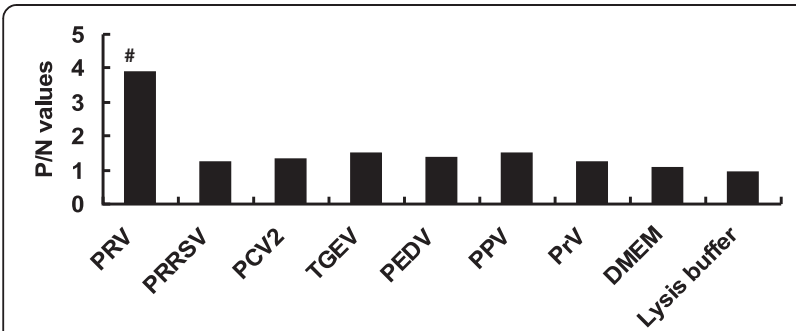

Figure 8 Discrimination ELISA. PRV, Porcine transmissible gastroenteritis virus (TGEV), Porcine epidemic diarrhea virus (PEDV), Porcine circovirus type II (PCV2), Porcine reproductive and respiratory syndrome virus (PRRSV), Porcine pseudorabies virus (PrV) and Porcine parvovirus (PPV), DMEM medium and virus lysis buffer were coated onto ELISA plates individually. The wells were incubated with the anti-PRV antibody followed by incubation of HRP-conjugated secondary antibody. The names of the pathogens are indicated in $x$ axis; The $\mathrm{OD}_{490}$ value of tested samples $(\mathrm{P}) /$ the $\mathrm{OD}_{490}$ value of negative control, coating buffer $(\mathrm{N})>2$ is judged as positive.

*compared with other group $(p<0.01)$. The P/N values were the mean values from three independent assays.

cultured in Luria-Bertani (LB) medium supplemented with Kanamycin $(50 \mathrm{mg} / \mathrm{mL})$ with shaking at $37^{\circ} \mathrm{C}$. When $\mathrm{OD}_{600}$ reached 0.6 , isopropyl beta-D-thiogalactoside (IPTG) was added to the medium to a final concentration of $1 \mathrm{mM}$ to induce protein expression. Control culture containing the same bacteria transformed with empty vector was used as control. The expressing protein designated as Pro-VP6 was subjected to gel-

Table 1 Information of PRV VP6 genes used in this study

\begin{tabular}{lcc}
\hline Grouping & Virus name & Isolation place \\
\hline Procine rotavirus A & CRW-8 & Australia \\
Procine rotavirus A & RU172 & India \\
Procine rotavirus A & GD & China \\
Procine rotavirus A & $4 S$ & China \\
Procine rotavirus A & $4 F$ & China \\
Procine rotavirus A & JL94 & China \\
Procine rotavirus A & DN30209 & China \\
Rotavirus B stain & Bang373 & Bangladesh \\
Human rotavirus & B219 & Bangladesh \\
Procine rotavirus C & Cowden & USA \\
Human rotavirus C & WD534tc & USA \\
Human rotavirus C & Moduganari & Nigeria \\
Human rotavirus B & WH-1 & China \\
Rotavirus C stain & Wu82 & China \\
Procine rotavirus A & OSU & USA \\
Human rotavirus C & Preston & UK \\
Human rotavirus & TUCH & USA \\
Procine rotavirus A & Gottfried & USA \\
\hline
\end{tabular}

The grouping, name and origin of the PRV isolates used in this study are provided. purification, sodium dodecyl sulfate-polyacrylamide gel electrophoresis (SDS-PAGE) and renaturation by dialysis according to our previously reported protocols [28].

\section{Generation of polyclonal antibody to VP6}

Generation of polyclonal antiserum to Pro-VP6 was processed according to references with modifications [17-19,28]. A New Zealand rabbit was immunized with $2 \mathrm{~mL}$ of gel-purified Pro-VP6 $(1 \mathrm{mg} / \mathrm{mL})$ emulsified with equal amounts of Freund's complete adjuvant via subcutaneous injection. After ten days, $2 \mathrm{~mL}$ of the same antigen mixed with Freund's incomplete adjuvant were injected into the rabbit weekly at two intervals. Antiserum was collected from the peripheral blood of the rabbit.

The titration of the antiserum and its reaction with VP6 protein was determined using ELISA: Purified VP6 was coated onto ELISA plates at a final concentration of $5 \mu \mathrm{g} /$ well at $4^{\circ} \mathrm{C}$ overnight. The next day, the wells were incubated with blocking buffer at $37^{\circ} \mathrm{C}$ for $2 \mathrm{~h}$, after three washes with PBS-0.1\% Tween20 (PBST). The wells were incubated with serially diluted polyclonal antibodies at $37^{\circ} \mathrm{C}$ for $1 \mathrm{~h}$. Then the plates were incubated with goat anti-rabbit IgG conjugated with peroxidase (1:5000 dilution in $\mathrm{PBS}$ ) at $37^{\circ} \mathrm{C}$ for $1 \mathrm{~h}$, after three washes with PBST. OPD (o-Phenylenediamine dihydrochloride) substrate $(100 \mu \mathrm{L} /$ well $)$ was added and incubated for 15 min followed by stopping reaction with $2 \mathrm{M} \mathrm{H}_{2} \mathrm{SO}_{4}$. The $\mathrm{OD}_{490}$ values were determined an ELISA reader. In addition, the reactivity of the anti-VP6 antibody to PRV was also tested. Briefly, the purified PRV $\left(10^{4} \mathrm{PFU} / \mathrm{mL}\right)$ were coated onto ELISA plates $(100 \mu \mathrm{L} /$ well $)$ and the dilution of antiserum to Pro-VP6 or the control serum was $1: 2^{4}, 1: 2^{5}, 1: 2^{6}, 1: 2^{7}, 1: 2^{8}, 1: 2^{9}, 1: 2^{10}, 1: 2^{11}$ or $1: 2^{12}$. The other experimental steps were performed as above.

\section{Western blot}

Pro-VP6-containing bacterial protein and empty vectortransforming bacterial protein (negative control) were subjected to SDS-PAGE and transferred to a nitrocellulose (NC) membrane. Rabbit antiserum to Pro-VP6 was diluted 1:2,000 in PBS and was used to incubate the membrane at room temperature for $1.5 \mathrm{~h}$ followed by incubation with horseradish peroxidase (HRP)-conjugated goat anti-rabbit IgG (1:5000 dilution, Boster, China) for $1.5 \mathrm{~h}$. The protein bands were visualized using OPD.

\section{Indirect immunofluorescence assay (IFA)}

Baby hamster kidney (BHK) cells seeded onto 24-well plates were transfected with pVAX-VP6 using polyethylenimine (PEI) transfection agent (Sigma, China) according to the manufacturer's instructions. Empty vector-transfected cells were used as control. The cells were fixed with $4 \%$ PFA (polyformaldehyde) in PBS at 
room temperature for $20 \mathrm{~min}$ and quenched with $0.1 \mathrm{M}$ glycine in PBS. Then, the cells were washed three times with PBST and treated with or without $1 \%$ Triton X-100 for 10 min followed by incubation with anti-VP6 serum (1:200 dilution in PBS containing 0.1\% BSA) for $1 \mathrm{~h}$. After three washes with PBST, the cells were incubated with fluorescein isothiocyanate (FITC)-conjugated goat antirabbit IgG (1:200 in PBS containing 1\% BSA) for $1 \mathrm{~h}$ at $37^{\circ} \mathrm{C}$. After washing with PBST, the fluorescence signals were analyzed using fluorescence microscopy.

\section{Immunoreactivity of the anti-VP6 antibody to other control viruses}

To evaluate the immunoreactivity of the anti-VP6 antibody, a discrimination ELISA was established. PRV, Porcine transmissible gastroenteritis virus (TGEV) strain HR/DN1, Porcine epidemic diarrhea virus (PEDV) strain HLJBY, Porcine circovirus type II (PCV2) strain PCV2LJR, Porcine reproductive and respiratory syndrome virus (PRRSV) strain JilinTN1, Porcine pseudorabies virus (PrV) strain Kaplan and Porcine parvovirus (PPV) strain PPV2010 were treated with lysis buffer (0.1\% SDS, 10 $\mathrm{mmol} /$ liter Tris- $\mathrm{HCl}[\mathrm{pH} 7.4]$, and $1 \mathrm{mmol} /$ liter EDTA) followed by dilution in carbonate-bicarbonate buffer (15 mM Na $\mathrm{CO}_{3}, 35 \mathrm{mM} \mathrm{NaHCO}, \mathrm{pH}$ 9.6) and the pathogens were coated into ELISA plates $(8 \mu \mathrm{g} /$ well $)$ at $4^{\circ} \mathrm{C}$ overnight. Wells coated with DMEM or lysis buffer were used as control. The anti-PRV antibody was used as primary antibody in the above-mentioned ELISA to detect the pathogens. The $\mathrm{OD}_{490}$ value of tested samples $(\mathrm{P}) /$ the $\mathrm{OD}_{490}$ value of negative control, coating buffer $(\mathrm{N})>2$ was judged as positive. The experiment was performed in triplicate. Statistical analysis of the data was processed with SPSS 11.5 software; $p<0.05$ and $p<0.01$ were defined as statistically significant and statistically very significant, respectively.

\section{Competing interests}

The authors have no competing interests.

\section{Authors' contributions}

XR, JZ, QY, LC, XD, WZ, REB and YR carried out the molecular genetic studies, participated in the sequence alignment and drafted the manuscript. JZ, JZ, $F D, G L$ and XR carried out the immunoassays. JZ, LC, GL, YR, SS and XR participated in the design of the study. XR conceived of the study and participated in its design and coordination and helped to draft the manuscript. All authors read and approved the final manuscript.

\section{Acknowledgements}

Grant Sponsored by Chang Jiang Scholar Candidates Programme for Provincial Universities in Heilongjiang,CSCP, Program for New Century Excellent Talents in University of Ministry of Education of P.R. China (NCET-10-0144), and Research Team Program on Scientific and Technological Innovation in Heilongjiang Provincial University (2011TD001) to X.R.; Research Fund for the Doctoral Program of Higher Education of China (20114320120006), Major Research Foundation of Education Bureau of Hunan Province (11A050) to Q.Y.; National Natural Science Foundation of China (31172295) to G.L.; Supported by The State Key Laboratory of Reproductive Biology (Grant No. Y252694C01) to J.Z.; National Natural Science Foundation of China (31270187) to Y.R. are acknowledged for their support on Research.

\section{Author details}

${ }^{1}$ College of Veterinary Medicine, Northeast Agricultural University, 59 Mucai Street, Xiangfang District, Harbin 150030, China. ${ }^{2}$ School of Life Science, Inner Mongolia University for the Nationalities, Tongliao, Inner Mongolia, China. ${ }^{3}$ College of Veterinary Medicine, Hunan Agricultural University, 1 Nongda RoadFurong Disctrict, Changsha 410128, China. ${ }^{4}$ State Key Laboratory of Reproductive Biology, Institute of Zoology, Chinese Academy of Sciences, Beijing 100101, China. ${ }^{5}$ Department of Health, Chinese Armed Police forest Force Command, Beijing 100097, China.

Received: 23 February 2012 Accepted: 14 March 2013

Published: 22 March 2013

\section{References}

1. Carreño-Torres JJ, Gutiérrez M, Arias CF, López S, Isa P: Characterization of viroplasm formation during the early stages of rotavirus infection. Virol J 2010, 7:350.

2. Wakuda M, Ide T, Sasaki J, Komoto S, Ishii J, Sanekata T, Taniguchi K: Porcine rotavirus closely related to novel group of human rotaviruses. Emerg Infect Dis 2011, 17:1491-1493.

3. Junaid SA, Umeh C, Olabode AO, Banda JM: Incidence of rotavirus infection in children with gastroenteritis attending Jos university teaching hospital. Nigeria. Virol J 2011, 8:233.

4. Estes MK, Cohen J: Rotavirus gene structure and function. Microbiol Rev 1989, 53:410-449.

5. Estes MK, Kapikian AZ: Rotaviruses and their replication, p.1917-1974. In Fields virology, Volume 2. 5th edition. Edited by Fields BN, Knipe DM, Howley PM, Griffin DE, Lamb RA, Martin MA, Roizman B, Straus SE. Philadelphia, PA: Lippincott, Williams, and Wilkins; 2007

6. Lorrot M, Vasseur M: How do the rotavirus NSP4 and bacterial enterotoxins lead differently to diarrhea? Virol J 2007, 4:31.

7. Schumann T, Hotzel H, Otto P, Johne R: Evidence of interspecies transmission and reassortment among avian group $\mathrm{A}$ rotaviruses. Virol 2009, 386:334-343.

8. Solberg OD, Hasing MS, Trueba G, Eisenberg JNS: Characterization of novel VP7, VP4, and VP6 genotypes of a previously untypeable group A rotavirus. Virol 2009, 385:58-67.

9. Collins PJ, Martella V, Buonavoglia C, O'Shea G: Identification of a G2-like porcine rotavirus bearing a novel VP4 type, P [32]. Vet Res 2010, 41:73.

10. Novo E, Esparza J: Composition and topography of structural polypeptides of bovine rotavirus. J Gen Virol 1981, 56:325-335.

11. Liu M, Offit PA, Estes MK: Identification of the simian rotavirus SAI genome segment 3 product. Virol 1988, 163:26-32.

12. Conner ME, Estes MK, Graham DY: Rabbit model of rotavirus infection. J Virol 1988, 62:1625-1633.

13. Clark B, Desselberger U: Myristylation of rotavirus proteins. J Gen Virol 1988, 69:2681-2686.

14. Svensson L, Grahnquist L, Pettersson CA, Grandien M, Stintzing G, Greenberg HB: Detection of human rotaviruses which do not react with subgroup I- and II-specific monoclonal antibodies. J Clin Microbiol 1988, 26:1238-1240.

15. Yin J, Li G, Ren X, Herrler G: Select what you need: a comparative evaluation of the advantages and limitations of frequently used expression systems for foreign genes. J Biotechnol 2007, 127:335-347.

16. Ren X, Li G, Liu B: Binding characterization of determinants in porcine aminopeptidase $\mathrm{N}$, the cellular receptor for transmissible gastroenteritis virus. J Biotechnol 2010, 150:202-206

17. Ren X, Wang M, Yin J, Ren Y, Li G: Heterologous expression of fused genes encoding the glycoprotein 5 from PRRSV: a way for producing functional protein in prokaryotic microorganism. J Biotechnol 2010, 147:130-135.

18. Ren X, Liu B, Yin J, Zhang H, Li G: Phage displayed peptides recognizing porcine aminopeptidase $\mathrm{N}$ inhibit transmissible gastroenteritis coronavirus infection in vitro. Virol 2011, 410:299-306.

19. Ren X, Suo S, Jang YS: Development of a porcine epidemic diarrhea virus $M$ protein-based ELISA for virus detection. Biotechnol Lett 2011, 33:215-220.

20. Panadero R, Vázquez L, Colwell DD, López C, Dacal V, Morrondo P, Díez-Baños P: Evaluation of an antigen capture ELISA for the early diagnosis of Hypoderma lineatum in cattle under field conditions. Vet Parasitol 2007, 147:297-302. 
21. Li G, Hong J, Huo G, Ren X: Monoclonal antibodies against Stx1B subunit of Escherichia coli 0157:H7 distinguish the bacterium from other bacteria. Lett App/ Microbiol 2010, 51:499-503.

22. Adlhoch C, Kaiser M, Hoehne M, Marques AM, Stefas I, Veas F, Ellerbrok H: Highly sensitive detection of the group A Rotavirus using Apolipoprotein $\mathrm{H}$-coated ELISA plates compared to quantitative real-time PCR. Virol J 2011, 8:63.

23. Chen S: Isolation and characterization of porcine rotavirus and its VP6 gene cloning and expression in Escherichia coli, Dissertation for the Master Degree in Agriculture of Northeast Agricultural University, Harbin, China: Northeast Agricultural University; 2003:14

24. Laemmli UK: Cleavage of structural proteins during the assembly of the head of bacteriophage T4. Nature 1970, 227:680-685.

25. Saitou N, Nei M: The neighbor-joining method: a new method for reconstructing phylogenetic trees. Mol Biol Evol 1987, 4:406-425.

26. Wang M, Li G, Yin J, Ren X: Phylogenetic characterization of genes encoding for glycoprotein 5 and membrane protein of PRRSV isolate HH08. J Vet Sci 2009, 10:309-315.

27. Ren X, Yin J, Ma D, Li G: Characterization and membrane gene-based phylogenetic analysis of avian infectious bronchitis virus Chinese strain HH06. Virus Genes 2009, 38:39-45.

28. Liu B, Li G, Sui X, Yin J, Wang H, Ren X: Expression and functional analysis of porcine aminopeptidase $\mathrm{N}$ produced in prokaryotic expression system. J Biotechnol 2009, 141:91-96.

doi:10.1186/1743-422X-10-91

Cite this article as: Zhu et al:: Development of porcine rotavirus vp6 protein based ELISA for differentiation of this virus and other viruses. Virology Journal 2013 10:91.

\section{Submit your next manuscript to BioMed Central and take full advantage of:}

- Convenient online submission

- Thorough peer review

- No space constraints or color figure charges

- Immediate publication on acceptance

- Inclusion in PubMed, CAS, Scopus and Google Scholar

- Research which is freely available for redistribution 